\section{A water sensitive urban design framework for South Africa}

\author{
Lloyd Fisher-Jeffes, Kirsty Carden \& Neil Armitage
}

http://dx.doi.org/10.18820/2415-0495/trp71i1.1

Peer reviewed and revised November 2017

\begin{abstract}
South Africa (RSA) is a 'developing country' still facing the challenge of providing basic water services to a significant proportion of the population. Water security is increasingly a matter of major concern, with most of the surface water resources fully accounted for and poor water quality downstream of urban areas. Whereas service delivery and social upliftment are high on the political agenda, the challenge is to promote economic and social equity, whilst simultaneously ensuring environmental sustainability; this challenge is greatest in the rapidly growing urban areas. Alternative approaches to conventional urban water management, which account for these water-supply and -quality constraints as well as the impacts of extreme weather-related events, are thus required. It is postulated that, from a water-management perspective, this will require strategic planning for the wide-scale implementation of Water Sensitive Urban Design (WSUD) a systems-based approach that focuses on the interactions between the built form and water-resources management. This article describes a way forward for an integrated management (infrastructure and planning) approach for urban water. It defines what 'water sensitivity' might mean in the RSA context, and outlines the process that was followed to develop a framework and guidelines for implementing WSUD in South Africa. The four complementary components of the framework - research, vision, narrative, and implementation - highlight what will be required in order to manage the challenges facing the country's urban water sector and enable the transition towards water sensitivity.
\end{abstract}

Keywords: Developing countries, water framework, water sensitive cities, water sensitive urban design

\section{'N WATERSENSITIEWE STEDELIKE ONTWERPRAAMWERK VIR SUID-AFRIKA}

Suid-Afrika (RSA) is 'n 'ontwikkelende land' wat steeds die uitdaging ondervind om basiese waterdienste aan 'n beduidende deel van die bevolking te voorsien. Waterbeveiliging word toenemend ' $n$ saak van groot kommer, met die meeste oppervlaktewaterhulpbronne in ag genome en swak watergehalte stroomaf van stedelike gebiede. Aangesien dienslewering en maatskaplike opheffing hoog op die politieke agenda is, is die uitdaging om ekonomiese en maatskaplike billikheid te bevorder en terselfdertyd omgewingsvolhoubaarheid te verseker; hierdie uitdaging is die grootste in die vinnig groeiende stedelike gebiede. Alternatiewe benaderings tot konvensionele stedelike waterbestuur, wat verantwoordelik is vir hierdie watervoorsiening en gehaltebeperkings sowel as die impak van uiterste weerverwante gebeure, word dus vereis. Daar word aangevoer dat dit vanuit 'n waterbestuursperspektief strategiese beplanning vir die wydverspreide implementering van Water Sensitive Urban Design (WSUD) benodig - 'n stelselgebaseerde benadering wat op die interaksies tussen die bouvorm en waterhulpbronbestuur fokus. Hierdie artikel beskryf 'n pad vorentoe vir 'n geïntegreerde bestuur (infrastruktuur en beplanning) benadering vir stedelike water. Dit definieer wat 'watergevoeligheid' binne die RSA konteks kan beteken en beskryf die proses wat gevolg is om 'n raamwerk en riglyne vir die implementering van WSUD in Suid-Afrika te ontwikkel. Die vier komplementêre komponente van die raamwerk - navorsing, visie, vertelling en implementering - beklemtoon wat benodig word om die uitdagings van die land se stedelike watersektor te hanteer en die oorgang na watersensitiwiteit moontlik te maak.
Sleutelwoorde: Ontwikkelende lande, watersensitiewe stede, watersensitiewe stedelike ontwerp, waterraamwerk

\section{TLHOPHISO YA MORALO WA TLHOKOMELO YA METSI MOTSE SETOROPONG WA AFRIKA BORWA}

Afrika Borwa ke naha e tlasa ntshetsopele e ntseng e kopana le phepetso ya ho fana ka ditshebeletso tsa metsi tsa mantlha bakeng sa karolo e kgolo ya baahi. Poloko ya metsi e ntse e tswella pele ho ba kgathatso e kgolo, moo teng ho ikarabellwang ka botlalo mehloding e hodimo ya metsi, le boleng bo tlase ba metsi a tswang ka tlase dibakeng tsa ditoropo. Le hoja phano ya ditshebeletso le tokafatso ya setjhaba e le hodimo lenaneng la dipolotiki, phepetso ke ho kgothalletsa tekatekano ya moruo le ya setjhaba. Ka yona nako eo, ho netefatswe polokeho ya tikoloho, mme phepetso ena e kgolo ka ho fetisisa dibakeng tsa ditoropo tse holang ka sekgahla. Mekgwa e meng bakeng sa taolo e tlwaelehileng ya metsi a ditoropong e ikarabellang phanong ya metsi le ditshetisong tsa boleng, ha mmoho le dikgahlamelong tse kgolo tse amanang le boemo ba lehodimo, di a hlokahala. Ho hlahiswa hore ho tswa tjhebong ya ho laola metsi, sena se tla hloka tlhophiso ya maano bakeng sa ho phethahatsa thokomelo ya metsi motse setoropong (WSUD) katamelo e ka ba mokgwa o itshetlehileng hodima tsela e tsepamisitseng maikutlo ho ditshebedisanommoho tse dipakeng tsa mokgwa wa kaho kapa taolo ya disebediswa tsa metsi. Atikele ena e bontsha mokgwa wa ho tswella pele ka tsela ya taolo e kopantsweng (meralo ya motheo le thophiso) ya metsi a ditoropong. E hlakisa seo "tlhokomelo ya metsi" e se bolelang boemong ba Afrika Borwa, mme e hlalosa tsela e latetsweng ya ho hlahisa moralo le ditataiso bakeng sa ho phethahatsa WSUD Afrika Borwa. Dikarolo tsa sejwalejwale tse nne tsa moralo- diphuputso, tjhebelopele, ho phetela le ho phethahatsa - di hlakisa tse tla hlokwa bakeng sa ho laola diphepetso tse shebileng sektara ya naha ya metsi a ditoropong; mme di tla etsa phetoho bakeng sa tlhokomelo ya metsi.

Mantswe a sehlooho: Dinaha tse tlasa ntshetsopele, moralo wa metsi, ditoropo tse hlokomelang metsi, moralo wa motse setoropong wa thokomelo ya metsi

Dr Lloyd Fisher-Jeffes, Aurecon Consulting, P.O. Box 494, Cape Town, 8000 (formerly Department of Civil Engineering, University of Cape Town). Phone: +27 21526 5753; email: <Lloyd.Fisher-Jeffes@aurecongroup.com>

Dr Kirsty Carden, Department of Civil Engineering, University of Cape Town, Private Bag X3, Rondebosch 7701. Phone: +27 216505317 ; email: <kirsty.carden@uct.ac.za>

Prof. Neil Armitage, Department of Civil Engineering, University of Cape Town, Private Bag X3, Rondebosch 7701. Phone: +27 216502589 ; email: <neil.armitage@uct.ac.za> 


\section{BACKGROUND}

The vision of a Water Sensitive City (WSC), one where water is given due prominence in the design of urban areas, was first proposed by Wong \& Brown (2008: 2) at the 11 International Conference on Urban Drainage (ICUD). The concept of water sensitivity was drawn in part from the notion of ecocities (a city or part thereof that balances social, economic and environmental factors in order to achieve sustainable development, and attempts to minimise inputs in terms of energy, water and food, as well as outputs of waste), and specifically watercentric ecocities, which focus on the hydrological and ecological value of the urban landscape (Howe \& Mitchell, 2012: 172). As part of the WSC vision, Brown, Keath \& Wong (2008: 5) put forward a conceptual framework for visualising and 'benchmarking' the evolution towards water sensitivity through the adoption of what is termed Water Sensitive Urban Design (WSUD). ${ }^{1}$ The WSC vision is particularly pertinent in both South Africa (RSA) and other developing countries that are struggling to address the challenge of providing basic services - including water - to their people. This challenge is greatest in the rapidly growing urban areas; it is estimated that nearly $78 \%$ of South Africa's population of 51.7 million people (in 2016) live in cities and towns in both urban and rural areas, with this urbanising trend likely to continue (SACN, 2016: 32).

Water is recognised as a strategic national resource under considerable stress, with increasing concerns about poor water quality within, and downstream of urban areas (DWA, 2010: 16). The Barilla Group, Coca-Cola, International Finance Corporation, McKinsey \& Co., Nestlé S.A., New Holland Agriculture, SABMiller plc, Standard Chartered

1 In its broadest context, WSUD encompasses all aspects (water supply, sewerage and stormwater) of integrated urban water-cycle management, and represents a significant shift in the way in which water and related environmental resources and water infrastructure are considered in the planning and design of cities and towns, at all scales and densities (Fletcher et al., 2014).
Bank \& Syngenta (2009: 10) note that RSA “... is severely constrained by low rainfall, limited underground aquifers, and reliance on significant water transfers from neighbouring countries"; the country could face an average gap of $17 \%$ between projected demand and supply by 2030 , with some catchments predicted to face gaps of nearly $40 \%$. Water scarcity is exacerbated by the fact that many people in RSA live below the official poverty line. There are major discrepancies between the rich and the poor, as highlighted by the country's Gini coefficient of 0.65 (in 2014), which ranks as one of the highest worldwide (World Bank, 2017). Basic services (e.g., potable water, sanitation, stormwater drainage, refuse removal and electricity) are not available to a significant proportion of the population. The Barilla Group et al. (2009), DWAF (2004), Turton (2008), Muller, Schreiner, Smith, Koppen, Sally, Aliber \& Cousins (2009), Ashton (2000) as well as Scholes (2001) all highlight the social and economic consequences that water shortages could have on RSA. However, whilst water security is indeed a major concern, there is no reason why RSA should experience a water crisis, provided that existing systems are managed effectively (Muller et al., 2009: 36).

Brown et al's (2008: 5) vision for water sensitivity is thus relevant to RSA and may assist in addressing some of the challenges facing the country's water sector; however, it needs to be contextualised for the unique development challenges RSA is facing. This paper outlines the process of developing a framework and guidelines for implementing WSUD in RSA, as part of the Water Research Commission Project $\mathrm{K} 5 / 2071,{ }^{2}$ which was concluded in 2014 (Armitage, Fisher-Jeffes, Carden, Winter, Naidoo, Spiegel, Mauck \& Coulson, 2014). It defines what 'water sensitivity' might mean in the RSA context, motivates for adopting this vision, and describes a four-component framework to

\footnotetext{
2 'Water Sensitive Urban Design (WSUD) or Low Impact Design (LID) for improving water resource protection/conservation and reuse in urban landscapes'.
}

enable RSA to transition towards water sensitivity.

\section{WATER SENSITIVE CITIES IN A DEVELOPING COUNTRY CONTEXT}

A WSC is one where the management of the urban water cycle is undertaken in a 'water sensitive' manner. Brown et al. (2008: 9) took this to mean developing a city that integrates the normative values of environmental repair and protection, supply security, flood control, public health, amenity, liveability and economic sustainability, amongst others. Communities would be driven by the normative values of protecting intergenerational equity with regards to natural resources and ecological integrity, as well as by concern that communities and environments are resilient to climate change.

Society and individuals are reliant on a wide range of infrastructure, and urban water infrastructure is a small, but important part of the infrastructure on which society relies. The vision for WSCs is such that the urban water cycle is managed for the benefit of all and the environment is protected simultaneously; in essence, a WSC ensures the development of sustainable water infrastructure for urban areas.

It is clear that an innovative approach such as this, which involves the planning, design and implementation of systems that improve the use of water with regard to its consumption and quality, is required in RSA. That water needs to be a priority is widely acknowledged; for example, the National Climate Change Response White Paper encourages the development and use of WSUD principles to capture water in the urban landscape and to minimise pollution, erosion and disturbance. It also notes that "urban infrastructure planning must account for water supply constraints and impacts of extreme weather-related events" (RSA, 2011a: 21). WSUD offers a means of facilitating a transition to water sensitivity, thereby creating the potential to mitigate the negative effects of water scarcity; manage and reverse water pollution; develop 
social and intergenerational equity; increase sustainability, and develop resilience to natural disasters and climate change within water systems. It is suggested, however, that implementing WSUD in RSA presents both opportunities and challenges:

i) Institutions: The fragmented 'silo-management' of different aspects of the urban water cycle occurs because of the allocation of different responsibilities to different municipal departments. For example, stormwater management is often undertaken by roads departments, with stormwater being viewed as hazardous water that needs to be disposed of as rapidly as possible. In addition, water supply is often separated from sewage collection, treatment and disposal, resulting in poor integration of services.

ii) Champions: Various international cases (e.g., Taylor, 2010) have found that progress is likely to be more rapid where there is a 'champion' in a position of authority. Identifying and supporting champions is essential to introducing and embedding a WSUD approach in RSA. However, institutional silos have thus far generally precluded these initiatives from being followed by water and sanitation departments within local authorities.

iii) Ecosystem Goods and Services (EGS): The European Union's 6th Framework (FP6) project SWITCH (Sustainable Water management Improves Tomorrow's Cities' Health) proposed the valuation of ecosystem services as a means of motivating for the adoption of WSUD (Howe \& Van der Steen, 2008: 4). Similarly, in South Africa, research in the field of resource economics supports the view that EGS can be successfully used to convince residents and policymakers of the benefits of this approach (Roberts \& Diederichs, 2002). It is thus necessary to consider how the benefits of transitioning towards WSCs could be presented to different stakeholders. Table 1 indicates some of the likely areas of

Table 1: Likely interest areas for different stakeholders

\begin{tabular}{|l|l|}
\hline \multicolumn{1}{|c|}{ Stakeholder } & \multicolumn{1}{c|}{ Area of interest/Opportunities } \\
\hline Politicians & Provision of basic services; job creation \\
\hline City officials & Costs and ease of maintenance \\
\hline Private developers & Increased profit/public image \\
\hline Community interest groups & Job creation; public health and safety \\
\hline Environmental interest groups & Protection of the environment \\
\hline Private individuals & Additional costs/benefits per household \\
\hline
\end{tabular}

interest for the various target audiences.

iv) Equity: This includes dignity, ownership and respect. RSA already faces challenges in the delivery of services to the previously disadvantaged. Attempting to do this in an ecologically acceptable or water sensitive manner adds another layer of complexity. The government will find it difficult to implement water sensitive projects when basic services do not exist, unless these are accomplished simultaneously.

v) Adaptability and uncertainty: RSA has technical capacity and skills constraints at both local and national government levels, and it is crucial that any developments do not 'lock' the country into overly complex technologies in the long term. Furthermore, there is a great deal of uncertainty about the future, including climate change impacts, demographics, and the resulting water-demand patterns.

vi) Mitigation: Environmental impacts need to be managed. According to the World Bank (2011), RSA has the $42^{\text {nd }}$ highest (out of 224 countries) output of $\mathrm{CO}_{2}$ per capita. This is a powerful argument for a WSUD approach if this means reducing the need for energy-intensive water-treatment technologies (e.g., desalination of seawater).

\section{RESEARCH METHODOLOGY}

The SWITCH project, which concluded in 2011, provides a useful example of a "short-term, global experiment in the sociotechnical transition...of urban water planning and operational practices" (Butterworth, McIntyre \& da Silva Wells, 2011: 398). Founded on a systems approach to urban water management, it made use of action-oriented, demand-led research in 12 cities in both developed and developing countries to show how an interdisciplinary approach might accelerate change towards a more sustainable future (Howe \& Van der Steen, 2008: 3). Key outcomes for the SWITCH project included encouraging cities to consider alternatives to conventional ways of managing water in an integrated manner, thus facilitating a transition towards water sensitivity. While it undoubtedly had some major successes, the ending of the project also brought an end to its high levels of support (financial and capacity). In addition, the majority of the demonstration projects were sitescale initiatives, and, in particular, none of them dealt with conditions similar to those encountered in the unserviced and informal areas in RSA. RSA faces a 'wicked problem' in the delivery of services to those living in informal areas. As discussed, attempting to achieve this in a water sensitive manner adds another layer of complexity (Fisher-Jeffes, Carden, Armitage, Spiegel, Winter \& Ashley, 2012: 6). Capacity, skills and resource shortages further compound the problem.

The SWITCH approach of using Learning Alliances (LAs) - "platforms that bring together stakeholders from a range of institutions...to think, act and learn together, using action research to test ideas" (Butterworth et al., 2011: 3) - was thus adopted to enable researchers and local stakeholders to work together to create shared visions, analyse options, and develop new strategies for the management of urban water systems.

\subsection{Research approach}

An interdisciplinary and participatory research approach was used for the development of the framework, 
with the research team comprising academics and students from several universities (Cape Town, Stellenbosch, Western Cape, Witwatersrand, and Sheffield), as well as officials working with four of the major metropolitan municipalities in RSA.

\subsubsection{Workshops}

The first task associated with the research entailed a series of workshops held during July 2011 with officials from the Roads \& Stormwater, and Water and Sanitation Departments at the metropolitan municipalities of Cape Town, eThekwini, Johannesburg and Tshwane, as well as Drakenstein, a smaller local authority near Cape Town. The workshops were used to introduce the researchers to key municipal officials and to identify potential opportunities and threats to the implementation of sustainable approaches to urban water management in the respective municipalities. The workshop series concluded with a meeting in Cape Town where outcomes were analysed, research boundaries and objectives determined, and a plan for taking the project forward was developed.

One of the key findings of these workshops was that the concept of 'water sensitive' and the challenges and opportunities for 'water sensitivity' are context specific. Hence, the tools and designs developed for/in RSA and other developing countries will likely vary from those implemented in developed countries. For example, the most water sensitive stormwater intervention downstream of a poorly serviced informal settlement could well be the construction of a low-flow diversion to the municipal wastewater treatment works to manage pollution. This directly contradicts current regulations that stipulate the strict separation of stormwater and wastewater (e.g., CoCT, 2006: 3). Selecting water sensitive technologies could thus mean choosing the most appropriate/'fit-forpurpose' technology that optimally manages water in a specific context.
Existing WSUD guidelines from countries such as Australia (see, e.g., BMT WBM, 2009) have not been developed with the complexities of developing nations in mind. As a result, relevant guidelines for the realisation of WSUD concepts in RSA and other developing countries are required. The development of appropriate guidelines will be an iterative process over time, as more technologies are trialled and evaluated.

The workshops also identified an urgent need for capacity-building in RSA - initially among municipal officials, in particular, but thereafter among policymakers, consultants, and citizens (Fisher-Jeffes et al., 2012: 6). It was noted that simply publishing guidelines will not ensure the successful uptake of WSUD; there needs to be an intentional effort to engage with policymakers and/ or individuals who can leverage their positions to ensure that the concept of water sensitivity is written into local and national policy, thereby resulting in more technologies being trialled in RSA. It became clear that progress would likely be defined by four sequential steps ('4T' concept):

- Development of Tools (manuals, guidelines, etc.);

- Transfer of knowledge to appropriate officials;

- Application of Tactics such as getting policy makers to write the information into relevant documents for encouraging WSUD implementation, and

- Testing of water sensitive technologies and approaches through various Trials (pilot studies, small scale developments, etc.).

\subsection{2 'Learning Alliance' arrangements}

Limited resources - both financially to support travel on a regular basis across RSA, and in terms of the capacity/ability of individuals to become committed to the notion of a LA - posed a significant challenge for the research. For this reason, two separate groups of people made up the 'supra' LA. The first group comprised researchers from the University of Cape Town (UCT) and officials from the City of Cape Town Municipality who attended meetings when possible. The second, much larger group, which met far less frequently, was made up of the researchers from UCT and academics from the Universities of Stellenbosch and the Witwatersrand, as well as municipal officials from Cape Town, eThekwini (including Durban), Johannesburg, and Tshwane (including Pretoria).

The development of the framework was, to a large extent, made possible through the collective insights gleaned from regular meetings of the first group, which were reviewed by the second. All meetings were documented, and the minutes made available to the entire 'supra' LA via the project website and by email. Members were encouraged to provide comments and input as necessary. These comments were then reviewed and, where appropriate, incorporated into the framework. This approach ensured optimal use of the limited capacity and expertise in RSA.

\section{RESULTS - A FRAMEWORK FOR WSUD IN SOUTH AFRICA}

The LA concluded that, in order to understand urban water management in RSA, it was first important to define the critical terms and concepts of WSUD. With this clarity in mind, the four complementary components (research, vision, narrative, and implementation) of the framework could be developed in an attempt to manage the challenges facing the country's urban water sector and enable the transition towards water sensitivity.

\subsection{Terminology}

Engineers Australia (2006: 3) define WSUD as an approach to urban planning and design that integrates land and water planning and management into urban design, based on the premise that urban development and redevelopment must address the sustainability of water. Several different terms and concepts are embedded in this definition of WSUD. Throughout the 
framework-development process for RSA, terminology was found to be crucially important. Many definitions from literature are inappropriate or lacking for the RSA context and needed to be defined up front.

\subsubsection{Water sensitivity}

The concept of 'water sensitivity' referred to in Section 2 does not fully recognise the challenges of working in a developing country context. In a society of dramatic inequality such as RSA, social acceptance is the overriding consideration - without which progress will be severely hampered. The definition also fails to explain how individual values will be used to determine the 'community values' that are meant to govern urban design decisions. This is particularly problematic in RSA where the notion of 'community' (generally accepted as a group of people with a sense of collective purpose and a "feeling... of belonging" (McMillan \& Chavis, 1986: 10) is often notably absent, particularly in informal settlements where large movements of people in and out of these settlements can result in dual feelings of permanence and temporality (Mahlangu, 2017).

In RSA, there is a strong emphasis on equity in access to water - both in terms of direct access for productive purposes and the benefits from resource use. The concept of developmental water management, as described in the draft National Water Resource Strategy 2 (NWRS-2), has as its central premise that water plays a critical role in equitable, social and economic development in the country (DWA, 2012: 7). For the purposes of this research, it was, therefore, proposed that 'water sensitivity' be defined as the management of the country's urban water resources based on five principles selected from the National Water Act (RSA, 1998), the NWRS-2, the RSA Constitution (RSA, 1996) and the Dublin Principles (UN, 1992):

i) RSA is a water-scarce country;

ii) Access to adequate potable water is a basic human right enshrined in the Constitution of RSA: iii) Management of water should be based on a participatory approach involving users, planners and policymakers at all levels;

iv) Water has an economic value in all its competing uses and should be recognised as an economic good. This includes the recognition of ecosystem goods and services provided by systems reliant on water, and

v) Water is a finite and vulnerable resource, essential to sustaining all life and supporting development and the environment at large.

\subsection{2 'Urban design' vs. 'urban planning'}

The term 'urban design' was a significant point of discussion at each meeting, with recommendations that it needed to be changed or better defined, as it appeared to exclude the discipline of urban planning, thereby preventing certain important stakeholders from taking ownership of the ideals of water sensitivity. Even the notion that 'design' includes 'planning' was unacceptable to the majority of the stakeholders. Table 2 shows that the terms are intrinsically linked; however, in the RSA context, urban planners generally undertake planning, whereas engineers, architects, landscape architects, and scientists undertake design. Generally, urban planning considers the 'bigger picture'; in other words, the suburb, catchment, city, country or continent, and whether/how factors and changes in each of these could or should direct development/ redevelopment of an area. Urban design refers to a more local design of an area, in order to fit in with existing urban plans.

\subsubsection{Urban management}

Aside from the design and planning aspects, another issue for consideration in terms of the implementation of WSUD in RSA is urban management and, in particular, urban infrastructure management. This entails the operational and maintenance aspects, community awareness building and education, optimisation of the use of resources, and the identification of infrastructure needs so that planning may take place. Effective management is required for all urban infrastructure and not specifically for water infrastructure, in order to ensure that social, economic and ecological concerns are integrated into all planning and development processes within a city (see, e.g., Roberts \& Diederichs, 2002).

\subsubsection{Water sensitive Urban Design}

WSUD brings the concepts of 'water sensitivity' and 'urban design' together to ensure that 'urban design' is undertaken in a 'water sensitive' manner (Armitage et al., 2014: 4). The WSUD approach has recently been included in a number of RSA policies at both local and national levels, with the intention of using these policies as leverage for change, particularly within

Table 2: $\quad$ Urban design vs. urban planning

\begin{tabular}{|c|c|}
\hline Urban design & Urban planning \\
\hline $\begin{array}{l}\text { Urban design involves the arrangement } \\
\text { and design of buildings, public spaces, } \\
\text { transport systems, services, and amenities. } \\
\text { Urban design is the process of giving form, } \\
\text { shape, and character to groups of buildings, } \\
\text { to entire neighbourhoods, and to the city } \\
\text { (Urban Design, 2012). }\end{array}$ & $\begin{array}{l}\text { Urban planning is a technical and political } \\
\text { process concerned with the welfare of people, } \\
\text { control of the use of land, design of the urban } \\
\text { environment including transportation and } \\
\text { communication networks, as well as protection } \\
\text { and enhancement of the natural environment } \\
\text { (McGill, 2017). }\end{array}$ \\
\hline $\begin{array}{l}\text { Urban design is a well-recognised field } \\
\text { associated with the planning and architectural } \\
\text { design of urban environments, covering issues } \\
\text { that have traditionally appeared outside of the } \\
\text { water field, but nevertheless interact with, or } \\
\text { have implications to environmental effects on } \\
\text { land and water (Wong \& Ashley, 2006). }\end{array}$ & $\begin{array}{l}\text { Urban planning addresses both the } \\
\text { development of open land ('greenfield sites') } \\
\text { and the revitalization of existing parts of } \\
\text { the city, thereby involving goal-setting, data } \\
\text { collection and analysis, forecasting, design, } \\
\text { strategic thinking, and public consultation } \\
\text { (Encyclopaedia Britanica, 2012). }\end{array}$ \\
\hline
\end{tabular}


municipal environments, although it is recognised that not only urban and peri-urban environments could benefit from such an approach.

For this reason, the word 'urban' is, to a large extent, omitted when referring to this approach in RSA, with Water Sensitive Design (WSD) increasingly being used as the term to describe an approach that is considered the enabler for ensuring that local authorities move closer to meeting developmental goals in all settlements where people dwell, irrespective of scale.

\subsection{A framework for Water Sensitive Urban Design in South Africa}

The realisation of water sensitivity in $\mathrm{RSA}$ requires a significant shift in the manner in which urban water is currently managed. Historically, water systems were developed using a linear design approach; i.e., source, treat, transport, distribute, collect, treat and dispose - a technologically driven approach largely removed from the citizens it serves.

The framework, therefore, had to address several important questions:

- What are WSCs? What do we need to do to support a transition towards water sensitivity? How can this be achieved, especially with limited funding and capacity?

- What is the long-term goal?

- How can the WSUD 'message' be conveyed so that all stakeholders are 'speaking the same language'?

- How can generally undercapacitated municipalities be expected to transition to WSCs? What new governance systems would be required to influence a step change in this regard?

The framework was thus developed with four components:

i) Research - focused on building capacity (discussed in section 3.1);

ii) Vision - lays out the long-term direction;

iii) Narrative - agreed on by all stakeholders, and

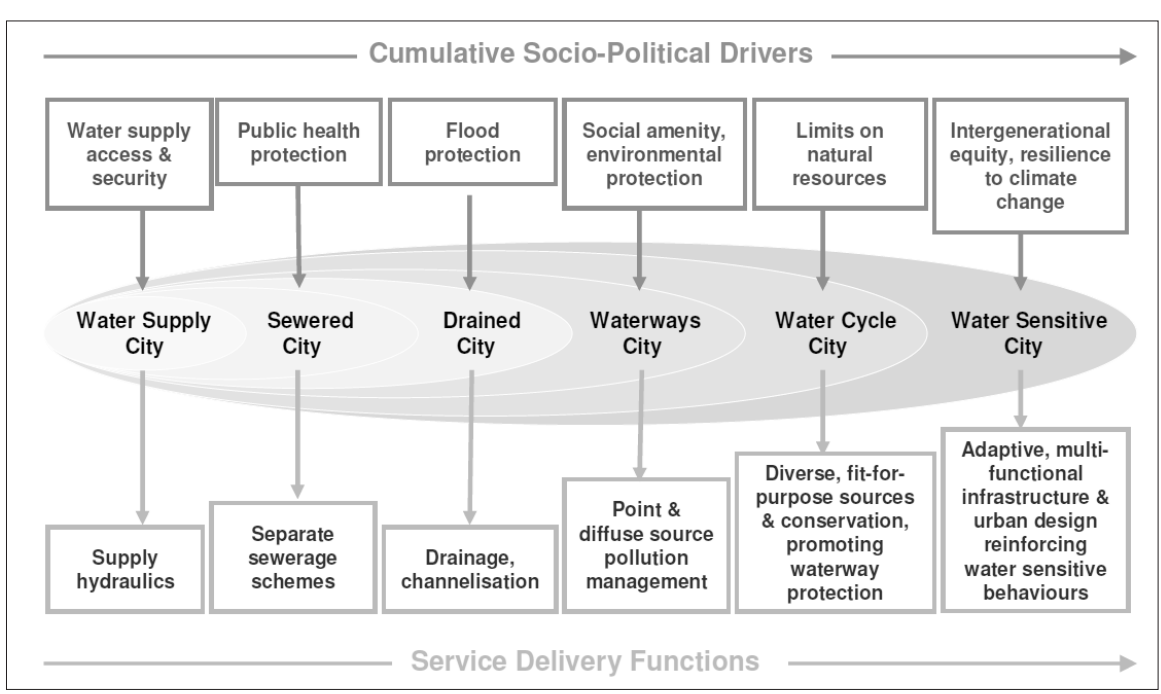

Figure 1: Urban water management transition states

Source: $\quad$ Brown et al., 2008: 5

iv) Implementation - a simple, but adaptable approach that may be applied to identify how best to use resources, in order to move towards the goal of water sensitivity.

\subsubsection{Vision}

The well-recognised 'Brown framework' (Brown et al., 2008: 5) for visualising transitions within the urban water-management sector (Figure 1) details the critical stages through which cities progress as they aim towards water sensitivity (Wong \& Brown, 2008). Six urban water transition states and their associated sociopolitical drivers and service delivery functions are identified and used to underpin the development of urban water transitions policy and to benchmark a city's progress (either forwards or backwards) at a macro scale.

As it is being envisaged mostly for cities in the developed world, the 'Brown framework' does not take into account the impact on the urban water cycle of a number of factors unique to RSA and other developing countries. It has thus been adapted for this context as shown in Figure 2.

Using the 'Brown framework', the majority of formally developed areas in RSA cities would fit the description of 'drained cities'. If RSA wishes to transition towards WSCs, in line with current international best practice, the legacy of apartheid needs to be taken into account. This policy of 'separate development' for different ethnic groups was "an instrument of crude social engineering, causing great hardship and imposing an unnecessary burden on the economy" (Turok, 1994: 243). In essence, the apartheid state refused to acknowledge "Africans as permanent urban inhabitants...investment in housing, infrastructure, education and other essential services in the townships was pared back from an already low level, in order to eliminate any such attractions the cities might offer to people from rural areas" (Turok, 1994: 246). This resulted in significant backlogs in infrastructure, which the current government is attempting to address. Typical of these backlogs are large numbers of poorly serviced informal settlements. Although the government has committed itself to upgrading these settlements, progress has been very slow and, currently, services are just as likely to be implemented as a response to civil unrest, pressure from NonGovernmental Organisations (NGOs), or in response to natural disasters, as part of any long-term plan.

Any attempt to transition to WSCs will need to consider both the formally developed areas in RSA cities (equivalent to settlements in Australia, North America and Europe) and the informal settlements, where high densities and limited 


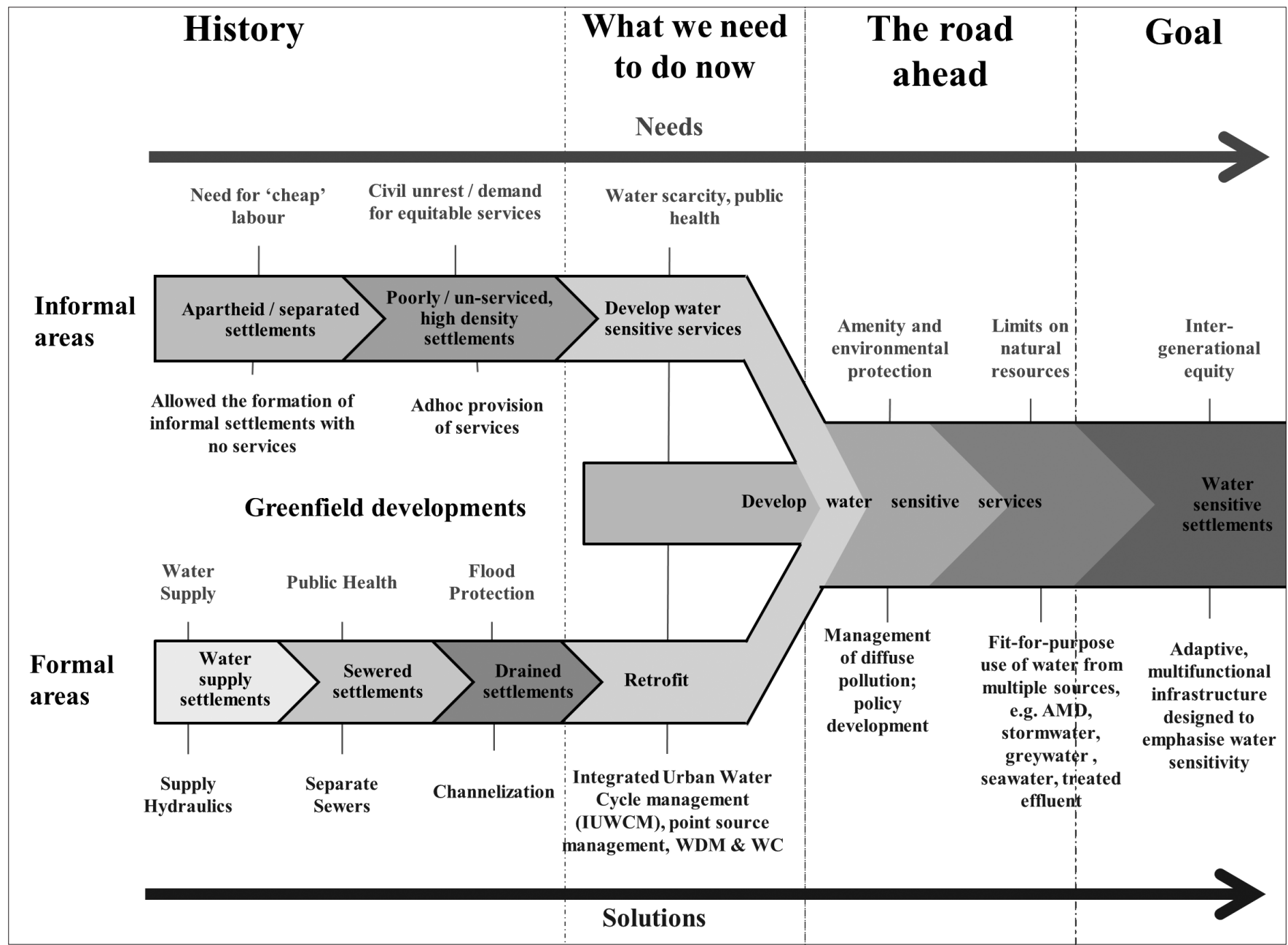

Figure 2: SA's transition to water sensitivity: "Two histories, one future"

Source: $\quad$ Adapted from Brown et al., 2008: 5

infrastructure are common. Figure 2 provides a vision of how it may be possible to influence the transition of both formal and informal areas in RSA:

i) Formal developed areas: Currently developed mostly as 'drained cities', these areas should attempt to transition towards water sensitive settlements through retrofitting and redeveloping in a water sensitive manner; i.e. through adopting integrated urban water cycle management, reducing point source pollution, and implementing Water Conservation and Water Demand Management initiatives.

ii) Informal areas: Once formal areas have begun to be retrofitted and the technologies tested in these areas, informal areas (currently developed as 'water supply cities' with limited sanitation) should be redeveloped in as water sensitive a manner as possible. Development of informal settlements should attempt to 'leapfrog' the stages through which formal areas develop, thus negating the need at a later stage to retrofit these areas. Using water sensitive technologies ('fit-for-purpose' use of water, management of diffuse pollution, multi-functional infrastructure, etc.) should also result in a range of secondary benefits for these communities. Care should, however, be taken to make certain that programmes are put in place to ensure adequate maintenance of the system/s.

iii) Greenfield (undeveloped) areas: Greenfield development should be undertaken in as water sensitive a manner as possible from the outset, particularly in the case of private developments, where the municipality can use development-planning approval processes to ensure that the concept of water sensitivity is incorporated.

It is important that the (re) development of informal areas in a water sensitive manner takes place simultaneously, with the residents of formal areas being educated and encouraged to retrofit their systems to be more water sensitive. To transition either formal or informal areas alone would not be possible in RSA; the 'burden, benefits and responsibility' of, and towards implementing WSUD must be borne by all residents. Ideally, this would lead to a point where both formal and informal areas transition to a 'waterway city' state. It would then be possible to move forward equitably and continue to transition towards water sensitivity. It should be noted, however, that current social, 
technical, physical, capacity, and financial constraints in RSA, along with an urgent need to improve conditions in informal areas, mean that it is unreasonable to expect informal areas to 'leapfrog' further than the 'waterway city' state.

\subsubsection{Narrative}

Narratives “... simplify and offer a stable vision and interpretation of reality and are able to rally diverse people around particular story lines" (Molle, 2008: 136). This concept may be applied to the WSC vision, where frameworks often fail to capture and express why the philosophy of WSUD should be adopted. The narrative 'tells the story', in order to draw people in; it expresses why water sensitivity is needed; how a WSC can be implemented, and what the outcome should be. The narrative for RSA (Figure 3) was developed to tie together the other three components of the framework, so that, at the very least, all stakeholders should understand and engage with the idea of a WSC.

\subsubsection{Implementation}

Various aspects are involved with the implementation of WSUD, including, inter alia, policy development; institutional structures; community participation; construction of infrastructure, as well as operation and maintenance. However, the most important consideration in RSA is how to transition to water sensitivity in the context of limited resources both human and financial.

What does the vision mean in practice? Are all cities expected to simultaneously achieve the status of WSCs in the foreseeable future? It seems unreasonable to expect a municipality with limited funding and capacity to retrofit all of its systems. Using the analogy of Maslow's hierarchy of needs (Maslow, 1943), municipalities need to ensure that they are at least meeting the physical water needs of their residents, whilst attempting to provide services that address the ideals of water sensitivity. This assertion is supported in RSA law and policy (e.g., RSA, 2011b). Currently, for example, where there is a failure to provide adequately for the disposal of greywater and/or to provide adequate sanitation, stormwater systems will likely become the default disposal system/sewer. In this case, the 'water sensitive' management of stormwater (i.e., the use of Sustainable Drainage Systems (SuDS) and other green infrastructure to convey and/or store stormwater) could pose a public health threat, deeming it unacceptable. Ultimately, all planning and expenditure should support the long-term realisation of the WSC goal. However, a municipality cannot focus on establishing ecosystem sustainability and intergenerational equity, unless it can simultaneously provide adequate and safe water to all of its citizens. Ideally, all development should incorporate the principles of water sensitivity. Conditions may, however, exist where this will not be possible (e.g., the emergency provision of water services in an informal settlement after a fire). Municipalities should thus target their initiatives with the underlying philosophy of 'Do what you can with what you have; till you get more to do something else'. This should be done while bearing in mind that, in achieving short-term goals, it is important not to jeopardise the long-term goal of a transition to water sensitivity. Furthermore, individuals and developers in formal areas often have the capacity to develop in a water sensitive manner independently of the local authority. Municipalities should, therefore, ensure that they strengthen local legislation and regulations to encourage this, thus freeing up resources for other areas.

As more trials are undertaken in RSA (an example of one of these trials is the recently completed WRC Project K5/2412, 'Challenges and opportunities for implementing Water Sensitive Design in South Africa' (Carden, Armitage, Fisher-Jeffes, Winter, Mauck, Sanya, Bhikha,

Mallett, Kanyerere \& Gxokwe, 2017), the implementation component will be strengthened. It will be possible to learn the lessons about where, when and how to implement the vision of WSCs in both formal and informal areas. It will also be possible to develop what, if any, preconditions there are for implementing the vision of WSCs in different areas of RSA. With this knowledge, it will then be possible to prioritise investment in order to realise maximum benefits for the future.

\section{DISCUSSION AND CONCLUSIONS}

RSA is a 'developing country' still facing the challenge of providing basic services, including water,

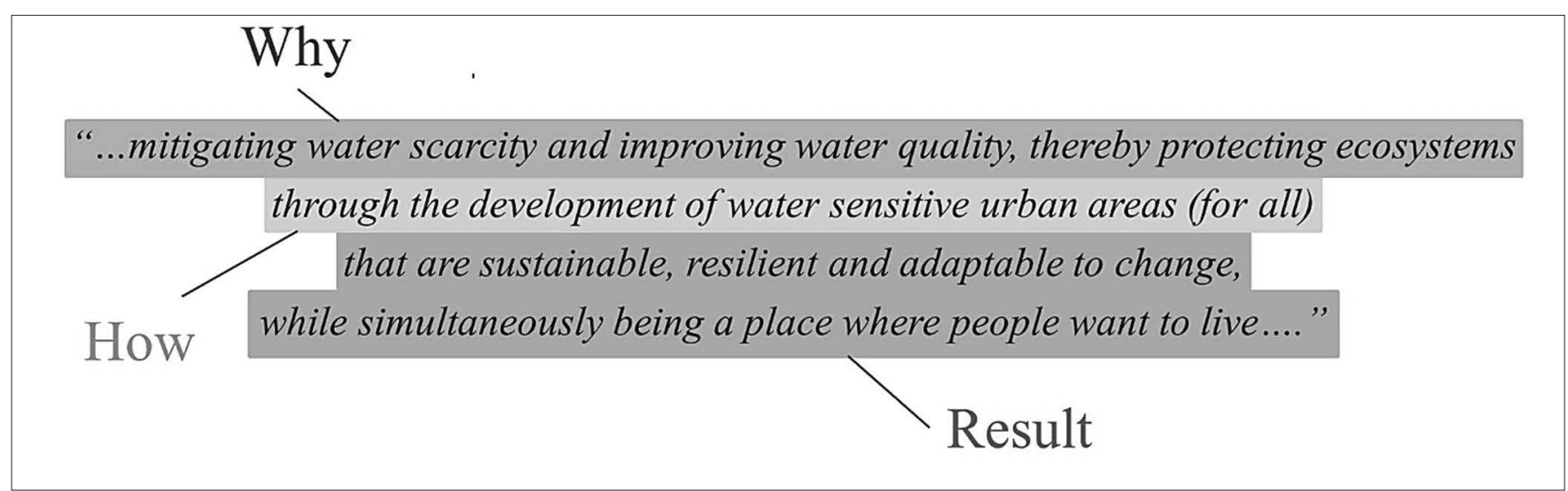

Figure 3: Suggested narrative for Water Sensitive Cities in South Africa 
to a significant proportion of the population, whilst some households are fully serviced to standards equal to any 'developed' nation. Water security is increasingly a matter of major concern, with the majority of the surface-water resources fully accounted for and poor water quality downstream of urban areas. Partly as a result of its apartheid history, RSA is one of the most 'unequal' countries in the world, as illustrated by its Gini coefficient ranking. Whereas service delivery and social upliftment are high on the political agenda, the challenge is to promote economic and social equity, whilst simultaneously ensuring environmental sustainability. This challenge is greatest in the rapidly growing urban areas. It is postulated that, from a water-management perspective, this will require strategic planning for, and the adoption of, WSUD to achieve the ultimate goal of water sensitivity. Using the Brown framework as a starting point, the interdisciplinary and participative ('LA') approach adopted for this study helped build an understanding of what 'water sensitivity' means within the complex developmental context of RSA. Whilst the four-component framework is specifically geared for the RSA context, the lessons learnt and approach used could be widely applied in other developing countries facing similar challenges (e.g., limited capacity, limited resources), where the setting up of conventional LAs, demonstration projects, and importing of skills is not always possible. Ideally, all cities should be 'water sensitive'. What this means in different country contexts and defining key terms within these contexts is crucial. Context is also vitally important when attempting to identify opportunities to 'leapfrog' development stages and determine how this may be achieved (e.g., to take into account that it may be technically possible, but not socially acceptable).

Whilst the achievement of WSCs in RSA may not seem to be wholly realistic, it should be remembered that this is a long-term vision, with no specific deadline for implementation. Having this vision means that, as far as possible, and within the means available, decision-makers in RSA cities are encouraged to continuously improve the integration of the planning and management of their urban water systems, with a view to transitioning 'closer' to the ideals of water sensitivity. This will ensure that alternatives to conventional urban water management will always be considered.

\section{As RSA continues to face the} challenges of water scarcity and declining water quality, the relevance of WSUD increases. The fourcomponent framework for achieving WSCs provides a way forward in this regard (Armitage et al., 2014). The research component can be used to build the knowledge and capacity required to adopt the long-term vision, while the narrative sets the scene for engaging with stakeholders and decision-makers in an effort to plan for and manage the challenges facing the country's urban water sector. Finally, the implementation component addresses the trade-offs that may be required in determining the best use of a range of 'fit-for-purpose' water resources (i.e., surface water, storm-/ rainwater, seawater, treated effluent, greywater, etc.) for developing multifunctional urban areas that are resilient and adaptable to change, as well as addressing development and equity issues.

\section{ACKNOWLEDGEMENTS}

This project was funded by the South African Water Research Commission (Project K5/2071).

\section{REFERENCES}

ARMITAGE, N., FISHER-JEFFES, L., CARDEN, K., WINTER, K., NAIDOO, N., SPIEGEL, A., MAUCK, B. \& COULSON, D. 2014. Water Sensitive Urban Design (WSUD) for South Africa: Framework and guidelines. WRC Report no. TT 588/14. Pretoria: Water Research Commission.

ASHTON, P. 2000. Integrated catchment management - balancing utilization and conservation. Pretoria: CSIR, Division of Water, Environment \& Forestry Technology.

BMT WBM. 2009. Evaluating options for Water Sensitive Urban Design A national guide. Australia: BMT WBM,
Joint Steering Committee for Water Sensitive Cities.

BROWN, R., KEATH, N. \& WONG, T. 2008. Transitioning to water sensitive cities: Historical, current and future transition states. In: Proceedings of the $11^{\text {th }}$ International Conference on Urban Drainage, 31 August-5 September 2008, Edinburgh International Conference Centre, Scotland. Edinburgh: IAHR/IWA.

BUTTERWORTH, J., MCINTYRE, P. \& DA SILVA WElls, C. (Eds). 2011. SWITCH in the city: Putting urban water management to the test. The Hague, The Netherlands: IRC International Water and Sanitation Centre.

CARDEN, K., ARMITAGE, N., FISHERJEFFES, L., WINTER, K., MAUCK, B., SANYA, T., BHIKHA, P., MALLETT, G., KANYERERE, T. \& GXOKWe, S. 2017. Challenges and opportunities for implementing Water Sensitive Design in South Africa. Final report for WRC Project K5/2412. Pretoria: Water Research Commission.

COCT (CITY OF CAPE TOWN). 2006. Wastewater and industrial effluent bylaw. Promulgated 1 September 2006 by Western Cape Provincial Gazette 6378.

DWA (DEPARTMENT OF WATER AFFAIRS). 2010. Integrated water resource planning for South Africa. A synopsis of the situation for key systems: 2010. Information booklet, October 2010. Pretoria: Directorate National Water Resource Planning, Department of Water Affairs.

DWA (DEPARTMENT OF WATER AFFAIRS). 2012. Proposed National Water Resource Strategy 2 (NWRS-2): Summary. Managing water for an equitable and sustainable future. Pretoria: Department of Water Affairs.

DWAF (DEPARTMENT OF WATER AFFAlrs). 2004. National water resource strategy. $1^{\text {st }}$ edition. Pretoria: Department of Water Affairs.

ENCYCLOPAEDIA BRITANNICA. 2012. Definition of urban planning. [Online]. Available at: <http:// www.britannica.com/EBchecked/ topic/619445/urban-planning> [Accessed: September 2012].

ENGINEERS AUSTRALIA (Ed.). 2006. Introduction. In: Wong, T.H.F (Ed.). Australian runoff quality: A guide to water sensitive urban design. Crows Nest, N.S.W.: Engineers Media, pp. 1-8. 
FISHER-JEFFES, L.N., CARDEN, K., ARMITAGE, N.P., SPIEGEL, A., WINTER, K. \& ASHLEY, R. 2012. Challenges facing implementation of Water Sensitive Urban Design in South Africa. In: Deletic, A. \& Fletcher, T. (Eds). Proceedings of the $7^{\text {th }}$ Conference on Water Sensitive Urban Design, 2-7 April 2006, Grand Hyatt Melbourne, Australia. Clayton, Vic.: Monash University, pp. 1-8.

FLETCHER, T., SHUSTER, W., HUNT, W., ASHLEY, R., BUTLER, D., ARTHUR, S., TROWSDALE, S., BARRAUD, S., SEMADENI-DAVIES, A., BERTRAND-KRAJEWSKI, J.-L., MIKKELSEN, P., RIVARD, G., UHL, M., DAGENAIS, D. \& VIKLANDER, M. 2014. SUDS, LID, BMPs, WSUD and more - The evolution and application of terminology surrounding urban drainage. Urban Water Journal, 12(7), pp. 525-542. doi:10.1080/157306 2X.2014.916314. https://doi.org/10.108 0/1573062X.2014.916314

HOWE, C. \& MITCHELL, C. (Eds.) 2012. Water sensitive cities. London: IWA Publishing.

HOWE, C. \& VAN DER STEEN, P. 2008. SWITCH: A systems approach to urban water management. Delft, The Netherlands: UNESCO-IHE Institute for Water Education.

MAHLANGU, S. 2017. A sense of place and belonging: Creating good neighbourhoods through productive social infrastructure. Unpublished dissertation (M.Arch. (Prof.)). Pretoria: University of Pretoria, Department of Architecture.

MASLOW, A. 1943. A theory of human motivation. Psychological Review, 50(4), pp. 370-396. https://doi. org/10.1037/h0054346

MCGILL. 2017. About urban planning. McGill School of Urban Planning, McGill University, Canada. [Online]. Available at: <https://mcgill.ca/ urbanplanning/planning $>$ [Accessed: 15 May 2017].

McMILLAN, D. \& CHAVIS, D. 1986. Sense of community: A definition and theory. Journal of Community Psychology, 14(1), pp. 6-23. https://doi.org/10.1002/15206629(198601)14:1<6::AIDJCOP2290140103>3.0.CO;2-I

MOLLE, F. 2008. Nirvana concepts, narratives and policy models: Insight from the water sector. Water Alternatives, 1(1), pp. 131-156.
MULLER, M., SCHREINER, B., SMITH, L., KOPPEN, B.V., SALLY, H., ALIBER, M., COUSINS, B., TAPELA, B., VAN DER MERWEBOTHA, M. \& KARAR, E. 2009. Water security in South Africa. Development Planning Division Working Paper Series. Halfway House: Development Bank of Southern Africa.

ROBERTS, D. \& DIEDERICHS, N. 2002. Durban's local agenda21 programme: Tackling sustainable development in a post-apartheid city. Environ Urban, 14(1), pp. 189-201. https://doi. org/10.1177/095624780201400116

RSA (REPUBLIC OF SOUTH AFRICA). 1996. Constitution of the Republic of South Africa, Act No. 108 of 1996. Pretoria: Government Printer.

RSA (REPUBLIC OF SOUTH AFRICA). 1998. National Water Act. Act No. 36 of 1998. Pretoria: Government Printer.

RSA (REPUBLIC OF SOUTH AFRICA). 2011a. National Climate Change Response White Paper. Pretoria: Government Printer.

RSA (REPUBLIC OF SOUTH AFRICA). 2011b. National Development Plan. Pretoria: National Planning Commission.

\section{SACN (SOUTH AFRICAN CITIES}

NETWORK). 2016. State of

South African Cities Report 2016.

Johannesburg: South African

Cities Network.

SCHOLES, R. 2001. Regional implementation plan for Southern Africa. [Online]. Available at: <http:// www.fao.org/gtos/doc/pub21.pdf> [Accessed: September 2012].

TAYLOR, A. 2010. Sustainable urban water management: The champion phenomenon. Unpublished Ph.D. thesis. Melbourne, Australia: Monash University, Sustainable Development Institute.

THE BARILLA GROUP, THE COCA-COLA COMPANY, THE INTERNATIONAL FINANCE CORPORATION, MCKINSEY \& CO., NESTLÉ S.A., NEW HOLLAND AGRICULTURE, SABMILLER PLC, STANDARD CHARTERED BANK \& SYNGENTAAG. 2009. Charting our water future: Economic frameworks to inform decision-making. 2030 Water Resources Group, McKinsey \& Co. [Online]. Available at: <http:// www.mckinsey.com/client_service /sustainability/latest_thinking/ charting_our_water_future> [Accessed: August 2012].

TUROK, I. 1994. Urban planning in the transition from apartheid: Part 1: The legacy of social control. The Town Planning Review, 65(3), pp. 243-259. https://doi.org/10.3828/ tpr.65.3.j03p90k7870q80g4

TURTON, A., 2008. Three strategic water quality challenges that decisionmakers need to know about and how the CSIR should respond. CSIR/NRE/ WR/EXP/2008/0160/A. Paper prepared for the CSIR Conference 'Science Real and Relevant', November 2008, Pretoria, South Africa.

UN (UNITED NATIONS). 1992. Dublin statement on water and sustainable development. Report from International Conference on Water and the Environment (ICWE), Dublin, Ireland.

URBAN DESIGN. 2012. Definition. [Online]. Available at: <http://www. urbandesign.org/urbandesign.html> [Accessed: September 2012].

WONG, T. \& ASHLEY, R. 2006. International Working Group on Water Sensitive Urban Design. Submission to the IWA/IAHR Joint Committee on Urban Drainage, IWA, London.

WONG, T. \& BROWN, R. 2008. Transitioning to water sensitive cities: Ensuring resilience through a new hydro-social contract. In: Proceedings of the $11^{\text {th }}$ International Conference on Urban Drainage, 31 August-5 September 2008, Edinburgh International Conference Centre, Scotland. Edinburgh: IAHR/IWA.

WORLD BANK. 2011. CO2 emissions (metric tons per capita) for South Africa. [Online]. Available at: <http://data. worldbank.org/indicator/EN.ATM.CO2E. PC> [Accessed: 15 October 2011].

WORLD BANK. 2017. The World Bank in South Africa - country overview. [Online]. Available at: <http://www. worldbank.org/en/country/southafrica/ overview> [Accessed: 2 October 2017]. 